\title{
Ideal Agricultural Agent as a Logical Solution and Investment
}

\author{
Dona Setia Umbara ${ }^{1, *}$, Lies Sulistyowati ${ }^{2}$, Trisna Insan Noor ${ }^{3}$, Iwan Setiawan ${ }^{4}$ \\ ${ }^{1}$ Faculty of Agriculture, Universitas Perjuangan, Tasikmalaya, Indonesia \\ ${ }^{2}$ Faculty of Agriculture, Universitas Padjadjaran, Jatinangor Sumedang, Indonesia \\ *Corresponding author: dsumbara.unper@gmail.com
}

Received November 17, 2018; Revised December 24, 2018; Accepted January 25, 2019

\begin{abstract}
Future agricultural quality is the result of efforts made by agricultural observers at the present time. An expectation of optimal future agricultural quality is a challenge for observers of agriculture in Saudi Arabia, specifically as a material for thought for agricultural extension workers. The role of agricultural extension agents is the spearhead sharpening the achievement of future agricultural goals. Therefore, the quality of agricultural extension agents becomes the starting point for achieving these objectives. Some of the competencies that must be possessed by agricultural extension workers so that they are worthy of being declared as ideal counselors who are able to view the future as a benchmark for developing agricultural concepts at this time, namely motive, innate competency, self-concept, knowledge and skills. Through the mastery of all these competencies, the agricultural instructor deserves to be declared as the ideal agricultural extension agent as a solution and investment in the future in a logical manner.
\end{abstract}

Keywords: extension, agriculture, solution, investment

Cite This Article: Dona Setia Umbara, Lies Sulistyowati, Trisna Insan Noor, and Iwan Setiawan, "Ideal Agricultural Agent as a Logical Solution and Investment.” World Journal of Agricultural Research, vol. 7, no. 1 (2019): 25-28. doi: 10.12691/wjar-7-1-5.

\section{Introduction}

Future agriculture is a very abstract hope and tends to be difficult to assume. The difficulty of assuming in this context is nothing but a prediction of an ideal future agricultural expectation [1]. Basically to provide an answer to this trend, it is considered important to make a diagnosis on the basis of achieving future agricultural expectations.

The purpose of the achievement platform is the current condition of agriculture which will serve as the starting point for designing a strategy to achieve future agricultural expectations. The diagnosis made on agricultural issues now needs to be done as part of the process of formulating the strategy. Through the diagnosis of current agricultural problems, it is hoped that the root causes of the problem will be clearly and authentically as well as conducting studies related to agricultural diseases that appear at this time which are then used as innovation materials to prepare the quality of agricultural products in the future [2].

Agricultural infrastructure is a facility that is very fundamental and is part of the mandatory requirements that must be met in an agricultural strategy. The strategy in question is part of the ethics of achieving future agricultural expectations. Therefore, the implementation of the stage of consideration is to fulfill the needs of agricultural infrastructure in a realistic manner [3].
The term that is relevant to the conditions of fulfilling agricultural infrastructure needs in a realistic manner is that an active stimulus is needed to achieve a positive response. The positive response in question is the ideal competency of farmers in conducting future agricultural preparation conditions. In this case, it is known as the farmer fist approach, whereas active stimulus can be interpreted in the context of agricultural infrastructure in the form of information transformation processes with respect carried out by agricultural extension agents as facilitators of human resource development (future farmer competencies) [4]. Through an intensive counseling process, it will be able to develop the quality of the human resources of farmers [5,6,7].

Based on the above explanation, in this context the agricultural extension is declared as one of the active stimulants. Farm extension is required to have optimum competence as the foundation for achieving stimulation goals against future farmers. Some core competencies that must be mastered by agricultural extension ideally include the motive competence, the innate competence, the selfconcept competence, the knowledge competence, and the skills [8]. Through the control of all these competencies, then agricultural extension can be declared as an investor in the achievement of a future agricultural goal.

The great expectation of ideal agricultural conditions in the future in particular is the dream of all elements of observing agriculture in Indonesia. To achieve these expectations, the role of investors must be able to provide 
real solutions logically and significantly. The real solution is logically and significantly, so an ideal agricultural instructor must be able to carry out experiments which in the end they find the problem as a real alternative solution based on his own experience [9]. Therefore, the role of the ideal extension agent is considered important because this role can be declared as a future agricultural investor. Based on the discussion, it can be concluded that the idelization of agricultural extension workers was declared as a logical investment solution to achieve future agricultural expectations.

\section{Discussion}

\subsection{Competence of Agricultural Extension Workers}

Competence of individuals as social beings and intense communication in this context as agricultural extension agents are required to have core competencies as follows [8]:

\subsubsection{Motive Competence}

Motive competency means the ability of the instructor to provide positive encouragement from within the instructor himself. This ability involves the concept of processing self emotions implicitly but can be revealed in the form of behavior when interacting with nature and the surrounding environment. Motivational competencies or self-management abilities greatly influence the behavior of instructors when interacting with extension participants (farmers). The effectiveness of communication in the delivery of information depends on the individual's mood. Basically if an instructor has been able to manage self emotions, then the motive competence can be realized optimally [10].

\subsubsection{Default Competence}

Innate competency is a natural competency possessed by agricultural extension workers since birth, whether in the form of psychological or physical, psychological, including something that is metaphysical, consisting of everything that is not visible or behind something visible, such as feelings, imagination, fantasy, etc., while body here is meant to physical aspects, such as body shape, nervous system, brain, muscle, and bone structure also affects the innate competency of an agricultural instructor. Mastery of innate competencies must be owned by an agricultural instructor so that he can take advantage of the nature of his possessions. The innate competency of each human being is different from one another, basically as an agricultural instructor must reflect themselves positively in order to provide positive energy to farmers to prepare the quality of agriculture in the future [11].

\subsubsection{Self-Concept Competence}

Self-concept that must be possessed by agricultural extension agents cannot be separated from discussion related to personality dynamics which include energy, voltage, value of needs, force or vector, movement, changes in structure and mental balance [12]. Energy means that every movement of an agricultural instructor believes that the existence of energy can affect his personal and views in providing motivation to farmers. The tension in the self-concept of an agricultural instructor can be used as a positive stimulation so that people are able to think analytically, critically, and logically to solve their problems. In addition, the self-concept of agricultural extension agents must be based on the value of future agricultural needs. This means that an agricultural instructor must be able to see the future as a reference for developing agricultural concepts at the present time. Force or vector is the direction of the agricultural instructor movement as a realization of the results of the coordination of the values of future agricultural needs. The realization of the results of the coordination of the value of the needs of future farmers must be actively stimulated in order to get a positive response from future farmers. Changes in psychological structure in the self-concept of extension agents can be interpreted that the stimulus given depends on the situation and conditions of the needs of the future agricultural environment. Finally, in the self-concept of agricultural extension workers must be able to apply the concept of mental balance so that extension workers can be received positively and voluntarily by farmers. In other words, agricultural instructors must be able to read all opportunities for the welfare of farmers by implementing market-based extension strategies [13]. Based on the results of these studies, it can be interpreted that agricultural extension workers must have comprehensive self-concept competencies.

\subsubsection{Knowledge Competence}

Knowledge is one of the competencies that must be possessed by agricultural instructors. As well as that the knowledge competence of agricultural extension agents has a very important role in the process of implementing motivation towards the future of farmers [14,15]. Knowledge competencies that must be embedded in the agriculture instructor must be based on the integration between theoretical studies and empirical studies related to agricultural values holistically [16]. The relevance of theoretical studies with empirical studies related to the basic concepts of agriculture is the main capital for agricultural extension agents as a basis for communication of information delivery logically, conservatively, innovatively, and realistically [17]. In addition, with the embedded competency of knowledge in self-educators, it can increase self-confidence to convince farmers that all forms of information conveyed are a truth that has a foundation $[18,19]$. The process of achieving the truth of the information base is considered important, that as an observer of agriculture, it is obligatory for them to have the skills to evaluate agricultural conditions as material knowledge and consideration of the development of future agricultural quality [20,21].

\subsubsection{Skills Competence}

Skills are competencies that must be possessed by agricultural extension workers. Skills are the actualization of what is already known and can then be practiced directly with farmers in the field. To master farming skills, of course, the intensity of field practice is needed as a material for meaningful direct experience [22]. Expectations here are not just about skills about agriculture, but how an agricultural instructor is skilled in 
motivating farmers to improve the quality of future farmer responses [23]. To get a positive response from farmers, innovations are delivered based on experimental results and show the success of the results of these experiments $[24,25,26]$.

\subsection{Agricultural Extension as a Future Farmer Foothold}

Becoming a quality farmer in the future is a logical hope in achieving the peak of happiness meaningfully. To reach the peak of the meaningful life of future farmers, optimal effort is needed in the form of real motives and motivations. Motive is an impulse that arises from within to reach the peak of life's achievements. While motivation is an impulse that comes from outside the peasant as a jack to reach the peak of this achievement. Boosting what is meant is a quality instructor who is able to invite farmers to look forward to realistically and significantly $[27,28]$. As the ideal extension agent to be able to become a jack for future farmers, the logical demand for them is to be able to comprehensively master the competency of agricultural instructors. Therefore, mastering these 5 competencies is a mandatory requirement for agricultural extension workers so that they are worthy of being a positive foundation for farmers in the future. The success of achieving the objectives of the farmer group movement is the result of the motivation of the agricultural instructors who are seen continuously inviting them to think innovatively [29,30].

\subsection{Ideal Agricultural Extension d Solutions AS an investment a Future}

Reflecting on the emergence of future agricultural problems in preliminary studies, the right solution is needed to reach the peak of hope. The current condition of the level of performance of agricultural extension workers to empower farmers is still not good [31]. Agricultural extension agents are a model and mirror for farmers to achieve quality future agricultural goals [32]. An alternative solution to solve this problem is through the idealization of agricultural extension workers. The ideal agricultural instructor is believed to have a visionary spirit to reach the peak of hope optimally. Ideal agricultural extension workers, they will behave professionally and be able to take realistic and systematic actions in the process of achieving future agricultural vision and mission. The concept is believed that the ideals of the quality of agricultural extension agents can contribute positively to the quality of farmers and future farmers [33]. Therefore, it can be concluded that the idealization of agricultural extension agents is a logical solution and investment to answer current agricultural problems in order to prepare qualified future farmers. Quality farmers and optimal agricultural products can improve the welfare and quality of life of farmers in the future [34].

\section{Conclusion}

Based on the results of the study related to the idealization of agricultural extension agents as a conceptual solution and logical investment can be concluded as follows:

1. Development of the quality of self-educators to reach the ideal point departs from self-motives and the application of the principle orientation towards achieving future agricultural quality.

2. The ideal agricultural extension agents are those who have innate competencies who are able to control their emotions and potential as a model of a quality and visionary future agricultural observer.

3. Agricultural extension personality competencies must reflect the authority and confidence of the farmers.

4. Development of the quality of knowledge of agricultural extension workers is an important aspect that must be carried out by them through direct research and experiment activities.

5. The self concept that is applied in the instructor is the determinant aspect of the level of trust of the farmers who are seen from the behavior and effectiveness of themselves as extension agents.

6. Competency of agricultural extension workers is a fundamental aspect that can be a benchmark for the level of self-worth as an ideal counselor.

\section{References}

[1] Aker, J. C. (2011). Agricultural Economics: Dial “A” for agriculture: a review of information and communication technologies for agricultural extension in developing countries. 42 (-) 631-647

[2] Bekeko, Z. at.al. (2018). Crop Protection: Combining ability and nature of gene action in maize (Zea mays L) inbred lines for resistance to gray leaf spot disease (Cercospora zeae maydis) in Ethiopia. 112 (-) 39-48.

[3] Glendenning, C. J., Babu, S. \& Okyere, K. A. (2010). INTERNATIONAL FOOD POLICY RESEARCH INSTITUTE: Review of Agricultural Extension in India. - (-) 1-31.

[4] Sadono, D. (2008). Jurnal Penyuluhan: Pemberdayaan Petani Paradigma Baru Penyuluhan Pertanian di Indonesia. 4 (1) 65-74. IPB: Bogor.

[5] Indraningsih, K. S. (2011). Jurna Agro Ekonomi: Pengaruh Penyuluhan terhadap Keputusan Petani dalam Adopsi Inovasi Teknologi Usaha Tani Terpadu. 29 (1) 1-24.

[6] Baloch, M. A. \& Thapa, G. B. (2016). Journal of the Saudi Society of Agricultural Sciences: The effect of agricultural extension services: Date farmers' case in Balochistan, Pakistan. - (-) -.

[7] Anzola, D. \& Cardenas, D. R. (2018). Cognitive Systems Research A Model of Cultural Transmission by Direct Instruction: An Exercise on Replication and Extension. - (-) -

[8] Spencer, M. L. \& Spencer, M. S. (1993). Competence at work: Models for superrior performance. New York: John Willy \& Son, Inc.

[9] Head, G. at.al. (2014). Crop Protection: Efficacy of Smart Stax insect-protected corn hybrids against corn rootworm: The value of pyramiding the Cry3Bb1 and Cry34/35Ab1 proteins. 57 (-) 38-47.

[10] Davis, K. E. (2008). Journal of International Agricultural and Extension Education: Extension in Sub-Saharan Africa: Overview and Assessment of Past and Current Models, and Future Prospects. 15 (3) $15-28$.

[11] Sujanto, A. Lubis, H. Hadi, T. (2009). Psikologi Kepribadian. Jakarta: Bumi Aksara

[12] Agwu, A. E. Dimelu, M.U. \& Madukwe, M. C. (2008). African Journal of Biotechnology: Innovation system approach to agricultural development: Policy implications for agricultural extension delivery in Nigeria. 7 (11) 1604-1611.

[13] Swanson, B. E. (2006). Journal of International Agricultural and Extension Education: The Changing Role of Agricultural Extension in a Global Economy. 13 (3) 5-17. 
[14] Cash, D. W. (2012). Science, Technology \& Human Values: "In Order to Aid in Diffusing Useful and Practical Information": Agricultural Extension and Boundary Organizations. 26 (4) 431-453.

[15] Chatterje, D., Dinar, A., \& Rivera, G. G. (2018). Technological Forecasting \& Social Change: An empirical knowledge production function of agricultural research and extension: The case of the University of California Cooperative Extension. - (-) -.

[16] Belay, K. (2003). Journal Of Social Development In Africa: Agricultural. Extension In Ethiopia: The Case Of Participatory Demonstration And'training Extension System. 18 (1) 49-84.

[17] Masoero, F. at.al. (2010). Animal Feed Science and Technology: Chemical composition and rumen degradability of three corn hybrids treated with insecticides against the European corn borer (Ostrinia nubilalis). 155 (-) 25-32.

[18] Ma, B. L. \& Subedi, K.D. (2005). Field Crops Research: Development, Yield, Grain Moisture and Nitrogen Uptake of Bt Corn Hybrids and Their Conventional Near-Isolines. 93 (-) 199-211.

[19] Hola, D. at.al. (2007). Journal of Plant Phisiology: Recovery of maize (Zea mays L.) inbreds and hybrids from chilling stress of various duration: Photosynthesis and antioxidant enzymes. $164(-)$ 868-877.

[20] Hayati, P. K. dkk. (2016). Penampilan jagung hibrida hasil silangtunggal dari berbagai kombinasi persilangan galur inbrida. 2 (2) 165-168.

[21] Febra, M. J. at.al. (2017). Algal Research: Development and characterization of hybrid corn starch-microalgae films: Effect of ultrasound pre-treatment on structural, barrier and mechanical performance. 28 (-) 80-87.

[22] Anderson, J. R. \& Feder, G. (2004). The World Bank Research Observer: Agricultural Extension: Good Intentions and Hadr Realities. 19 (1) 41-60.

[23] Katungi, E., Machethe, C., \& Smale, M. (2007). AfJARE: Determinants of social capital formation in rural Uganda: Implications for group-based agricultural extension approaches.
1 (2) $167-190$.

[24] Asiabaka, P. C. (1992). Promoting Sustainable Extension Approches: Farmer Field School (FFS) and its Role in Sustainable Agricultural Development in African. - (-) -.

[25] Ditu, L. M. at.al. (2011). Anaerobe: Modulation of virulence and antibiotic susceptibility of enteropathogenic Escherichia coli strains by Enterococcus faecium probiotic strain culture fractions. 17 (-) 448-451.

[26] Moyo, R. \& Salawu, R. (2018). Journal of Rural Studies: A survey of communication effectiveness by agricultural extension in the Gweru district of Zimbabwe. 60 (-) 32-42.

[27] Musyafak, A. \& Ibrahim, T. M. (2005). Strategi Percepatan dan Difusi Inovasi Pertanian Mendukung Prima Tani. 3 (1) 20-37.

[28] Kuusisto, J. \& Maloney, T. C. (2016). Industrial Crops and Products: Preparation and characterization of corn starch-calcium carbonatehybrid pigments. 83 (-) 294-300.

[29] Nuryanti, S. \& Swastika, D. K. S., (2011). Forum Penelitian Agro Ekonomi: Peran Kelompok Tani dalam Penerapan Teknologi Pertanian. 29 (2) 115-128.

[30] Niu, C. \& Ragasa, C. (2018). Agricultural System: Selective attention and information loss in the lab-to-farm knowledge chain: The case of Malawian agricultural extension programs. $165(-)$ 147-163.

[31] Marliati, dkk. (2008). Jurnal Penyuluhan: Faktor-faktor Penentu Peningkatan Kinerja Penyuluh Pertanian dalam Memberdayakan Petani. 4 (2) 92-99. IPB: Bogor.

[32] Sanz, V., Bergero, F., \& Urquia, A. (2017). Simulation Modelling Practice and Theory: An approach to agent-based modeling with Modelica. - (1-10) -

[33] Haug, R. (2007). The Journal of Agricultural Education and Extension: Some leading issues in international agricultural extension, a literature review. - (-) 37-41.

[34] Barlow, J. S., Bernand, J.K, \& Mullis, N. A. (2012). Journal of Dairy Science: Production response to corn silage produced from normal, brown midrib, or waxy corn hybrids. 95 (8) 4550-4555. 